\title{
NOTE
}

\section{Correlation of the Pituitary Response to Synthetic LH-RH to the Estradiol Levels in Anovulatory and Ovulatory Women}

\author{
Tsuguo UEMURA, JiRo KOOGUCHI, SHOICHI TSUCHIHASHI \\ AND YOSHINORI SHIOJIMA \\ Department of Obstetrics and Gynecology, Yokohama City University, \\ School of Medicine, Yokohama-shi 232
}

\section{Synopsis}

\begin{abstract}
This paper describes the LH and FSH responses to synthetic LH-RH in 81 anovulatory women and 37 ovulatory women at various estradiol (Ed) levels. Besides, effects of mestranol on releases of LH and FSH in response to LH-RH were examined in 4 anovulatory women. Subjects were divided into 3 groups: low Ed group, moderate Ed group and high Ed group.

No significant correlation was found in ovulatory women, but in anovulatory women a positive significant correlation was found between the $\mathrm{LH} / \mathrm{FSH}$ ratio after LH-RH injection and the circulating Ed level. In ovulatory women, a mean LH/FSH after administration of LH-RH was not significantly different from $\mathrm{LH} / \mathrm{FSH}$ at the $\mathrm{LH}$ peak in the normal menstrual cycle. But in anovulatory women, a mean LH/FSH after the adminitration in the low Ed group was significantly lower than LH/FSH and mean LH/FSH after the administration in two other Ed groups were significantly higher than that at the LH peak in the normal menstrual cycle. Among the low Ed group, four patients with primary ovarian failure and elevated gonadotropin levels in serum were treated with mestranol. With increased doses of mestranol, the LH/FSH after administration of LH-RH was increased and reached to the same level as the normal ovulatory peak in these 4 patients.

Our results demonstrated that responses of pituitary gonadotropins to LH-RH in anovulatory women were significantly different in the LH/FSH from those in ovulatory women. Abnormality of these responses in anovulatory women seems to be unfavorable to ovulation.
\end{abstract}

Variations in response to synthetic LHRH during different phases of the menstrual cycle are known. These variations may be due to changes in the ovarian secretion of sex steroid hormones during the menstrual cycle (Yen et al., 1972).

In our preliminary study (Uemura et al., 1975), effects of serum estradiol (Ed) on pituitary gonadotropin responses to synthetic LH-RH were examined in women without ovulatory menstrual cycles. The evidence revealed that there was a positive correlation between the ratio of $\mathrm{LH}$ to $\mathrm{FSH}(\mathrm{LH} / \mathrm{FSH})$ following administration of LH-RH and the circulating Ed level, and suggested that the responses of gonadotropins to LH-RH were affected by serum Ed levels and that serum Ed caused a differential release of $\mathrm{LH}$ and FSH in response to LH-RH. This paper describes that LH and FSH responses to synthetic LH-RH were modified by Ed levels in ovulatory women as well as anovulatory ones. 


\section{Materials and Methods}

One hundred and eighteen women ( 37 ovulatory women, 23-31 years of age and 81 anovulatory women, 21-34 years of age) were studied. A dose of $100 \mu \mathrm{g}$ synthetic LH-RH (Mochida Pharm. Co., Ltd.) was intramuscularly injected during the follicular phase (day 7 to 14). Serum levels of LH, FSH and Ed were determined before and $30 \mathrm{~min}$ after the administration, since $\mathrm{LH}$ and $\mathrm{LH} / \mathrm{FSH}$ show maximum values about $30 \mathrm{~min}$ after the injection in almost all cases (Kooguchi et al., 1976). LH and FSH levels in the serum were measured by the double antibody radioimmunoassay using LH-, FSH-RIA-kit (Calbiochem Co.) Ed levels were determined by the radioimmunoassay method of T. Makino (Makino, 1973), using the antiserum against Ed-6-oxime-BSA donated by Dr. A. Kanbegawa (Teikoku Hormone Mfg., Co.. Ltd.) and microcolumn chromatography of Sephadex LH-20 for purification. The standard preparation (Teikoku Hormone Mfg., Co., Ltd.) was used for the measurement of serum Ed.

Preliminary evidence on Ed levels during the normal menstrual cycle and in anovulatory women (Uemura et al., 1974) suggested that Ed level under $30 \mathrm{pg} / \mathrm{ml}$ indicates the presence of a small amount of Ed. Therefore, women were divided into 3 groups; a low Ed group that showed Ed levels under 30 $\mathrm{pg} / \mathrm{ml}$, a moderate Ed group that showed Ed levels from a $30 \mathrm{pg} / \mathrm{m} l$ to $99 \mathrm{pg} / \mathrm{m} l$ and a high Ed group that showed Ed levels over $100 \mathrm{pg} / \mathrm{ml}$. All ovulatory women belonged to the high Ed or the moderate Ed group. Student's $t$ test was used for statistical analysis.

\section{Results}

1. Serum LH and FSH levels before and after LH-RH injection

LH and FSH levels in serum before and after LH-RH injection were compared among the three groups (Table 1). Mean FSH levels before and after LH-RH injection were significantly higher in the low Ed group than those in the other groups. Conversely, a mean LH level after LH-RH injection was significantly higher in the high Ed group than those in the other groups.

Table 1. Correlation between LH and FSH responses to LH-RH and serum estradiol level in ovulatory and anovulatory women.

\begin{tabular}{|c|c|c|c|}
\hline & $\begin{array}{l}\text { less than } \\
30 \mathrm{pg} / \mathrm{m} l\end{array}$ & $\begin{array}{l}\text { TRADIOL LE } \\
30-99 \mathrm{pg} / \mathrm{m} l\end{array}$ & $\begin{array}{l}\text { more than } \\
100 \mathrm{pg} / \mathrm{m} l\end{array}$ \\
\hline No. of cases & 33 & 68 & 17 \\
\hline $\mathrm{LH}(\mathrm{mIU} / \mathrm{m} l)$ & $24.8 \pm 6.3$ & $19.3 \pm 1.7$ & $23.4 \pm 3.5$ \\
\hline $\mathrm{FSH}(\mathrm{mIU} / \mathrm{m} l)$ & $40.3 \pm 10.1^{* *}$ & $11.0 \pm 0.7$ & $12.7 \pm 1.1$ \\
\hline LH AFTER LH-RH $(\mathrm{mIU} / \mathrm{m} l)$ & $124.1 \pm 24.1$ & $162.2 \pm 14.7$ & $259.9 \pm 48.2^{* *}$ \\
\hline FSH AFTER LH-RH $(\mathrm{mIU} / \mathrm{ml})$ & $59.7 \pm 12.2^{* *}$ & $19.7 \pm 1.4$ & $\begin{array}{c}23.1 \pm 2.7 \\
(\text { Mean } \pm \text { S.E. })\end{array}$ \\
\hline
\end{tabular}

Significant difference: $\mathbf{P}<0.01 * *$

Table 2. Correlation between LH and FSH responses to LH-RH and serum estradiol level in ovulatory and anovulatory women.

\begin{tabular}{lccc}
\hline \hline & $\begin{array}{c}\text { ESTRADIOL LEVEL } \\
\text { less than } \\
30 \mathrm{pg} / \mathrm{m} l\end{array}$ & $\begin{array}{c}\text { more than } \\
100 \mathrm{pg} / \mathrm{m} l\end{array}$ & 17 \\
& 33 & 68 & $1.9 \pm 0.1^{* * *}$ \\
No. of cases & $0.8 \pm 0.1$ & $2.2 \pm 0.3^{* * *}$ & $11.5 \pm 2.1^{* * *}$ \\
LH/FSH (A) & $2.1 \pm 0.2$ & $10.6 \pm 1.4^{* * *}$ & $6.3 \pm 1.3^{*}$ \\
LH/FSH AFTER LH-RH (B) & $3.6 \pm 0.7$ & $6.0 \pm 0.6^{*}$ & (Mean \pm S.E.) \\
B/A & & &
\end{tabular}

Significant difference: $\mathbf{P}<0.05 * ; \quad \mathbf{P}<0.001 * * *$ 
2. LH/FSH before and after LH-RH injection

In order to clarify the difference in the three groups, LH/FSH before and after administration of LH-RH were examined (Table 2). A mean ratio in the low Ed group was significantly lower than those in the other groups before and after the administration, moreover, a percentage increase of the ratio was significantly less in the low Ed group than those in the other groups.

As the low Ed group consists of anovulatory women, the difference between ovulatory women and anovulatory women was studied. The correlation between $\mathrm{LH} /$ FSH after LH-RH injection and circulating Ed level in ovulatory women was shown in Fig. 1. No significant correlation $(r=$ 0.00480) was found between LH/FSH following administration of LH-RH and

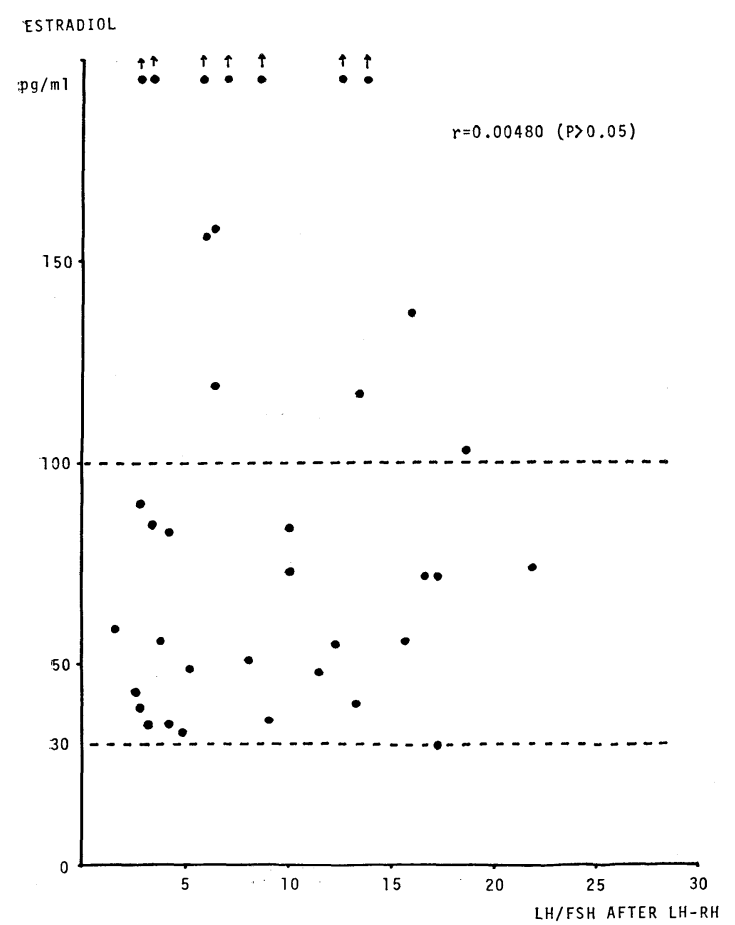

Fig. 1. Correlation between LH/FSH after LH-RH and serum estradiol level in ovulatory women. the circulating Ed level. In anovulatory women, a positive significant correlation $(r=0.43039, \mathrm{p}<0.001)$ was found between LH/FSH following administration of LH-RH and the circulating Ed level (Fig. 2).

3. Changes of LH/FSH during the follicular phase in normal menstrual cycles

The ratios of $\mathrm{LH}$ to FSH during the follicularphase were calculated in 14 women with normal menstrual cycles (Fig. 3). There is a gradual increase in LH/FSH, reaching a maximum value of $7.0 \pm 0.8$ (Mean \pm SE) at the LH peak (Day 0). In anovulatory women, a mean LH/FSH of the low Ed group was lower and means of LH/FSH of the other groups were higher than those at the follicular phase in the normal menstrual women.

In ovulatory women, a mean LH/FSH after administration of LH-RH was not

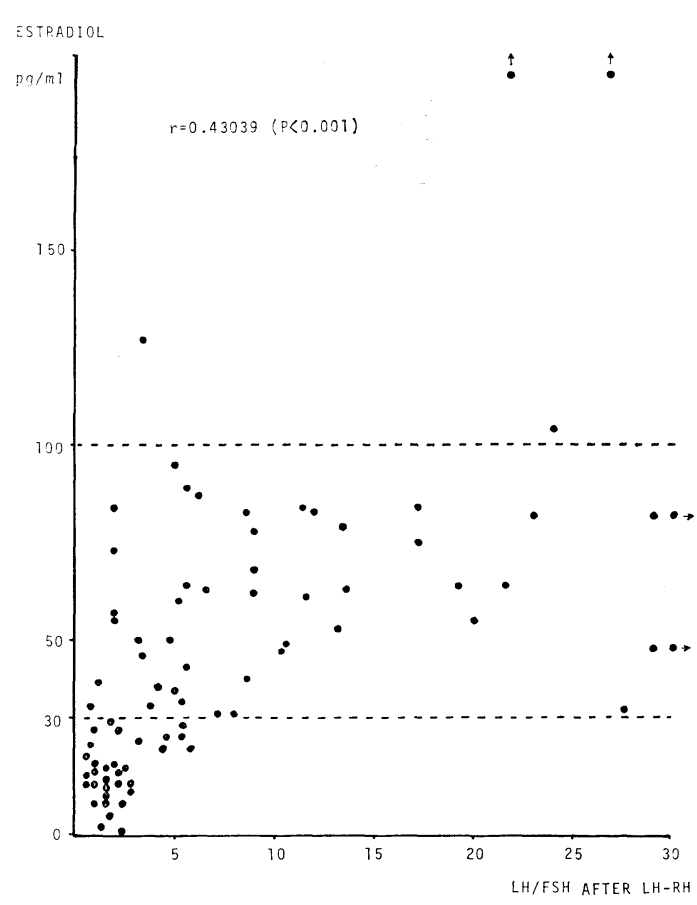

Fig. 2. Correlation between LH/FSH after LH-RH and serum estradiol level in anovulatory women. 
significantly different from $\mathrm{LH} / \mathrm{FSH}$ at the LH peak. But in anovulatory women, a mean LH/FSH after the administration in the low Ed group was significantly lower $(\mathrm{p}<0.001)$, and mean LH/FSH after the administration in the other groups was significantly higher $(\mathrm{p}<0.05)$ than that at the LH peak in the normal menstrual cycle (Fig. 3).

4. Effects of mestranol on releases of $\mathrm{LH}$ and $\mathrm{FSH}$ in response to LH-RH

Four patients with primary ovarian failure who showed low Ed levels and elevated gonadotropin levels in serum, were treated with mestranol (ethinylestradiol-3methylether) and studied on the releases of $\mathrm{LH}$ and FSH in response to LH-RH. Daily oral doses of mestranol were increased week by week, 40,80 and $320 \mu \mathrm{g}$ per day, respectively.

Fig. 4 shows changes in the responses of one patient. After increasing the doses of mestranol, a release of FSH in response to LH-RH was decreased, but a release of

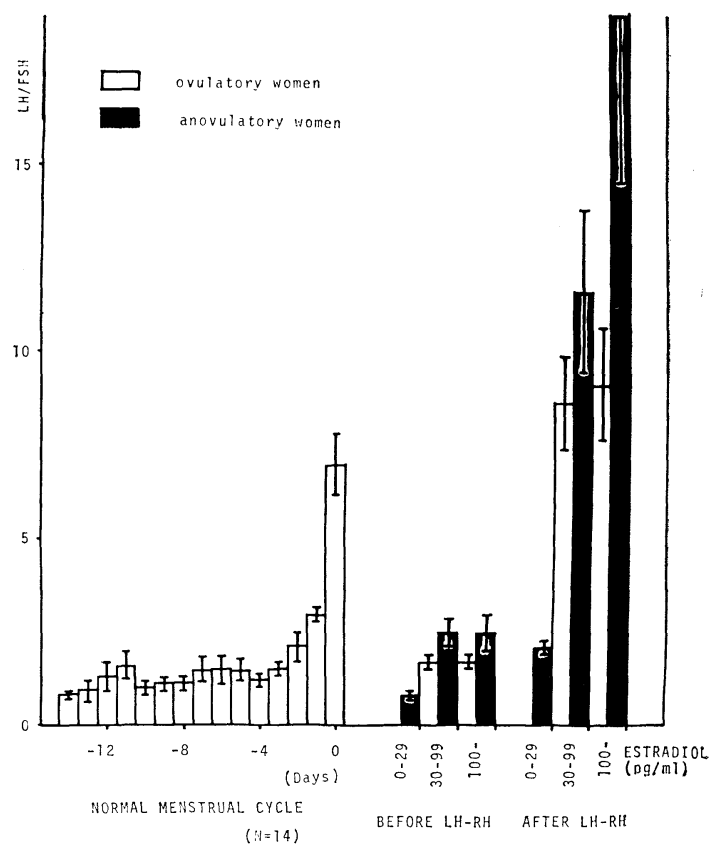

Fig. 3. LH/FSH after LH-RH in ovulatory women and anovulatory women (mean $\pm \mathrm{SE}$ ).

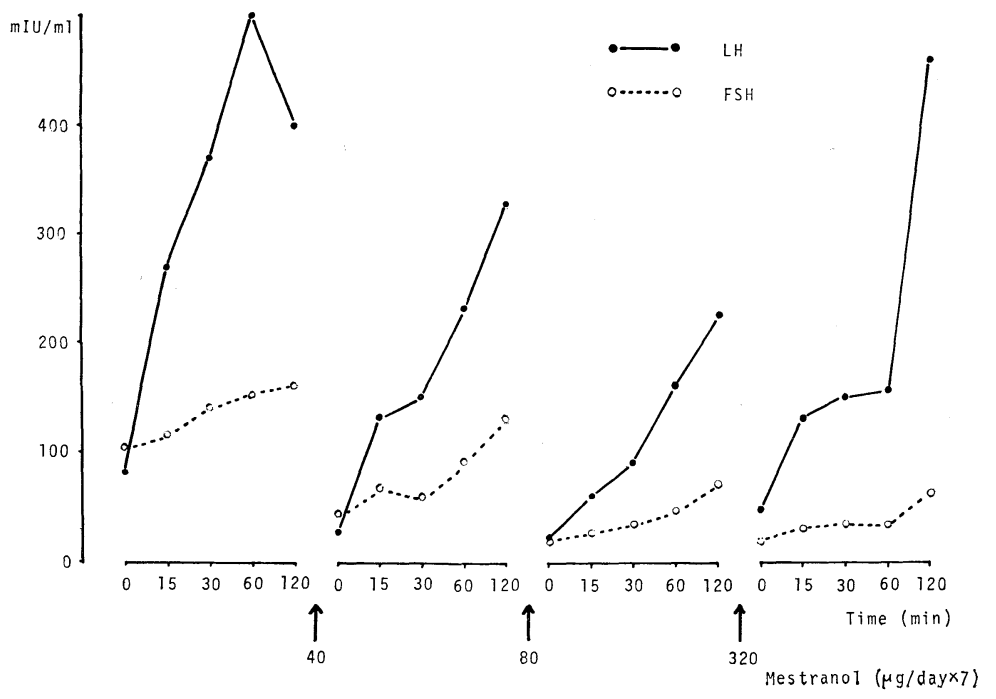

Fig. 4. Serum LH and FSH levels after LH-RH administration to a patient with a high gonadotropin level who was primed with mestranol. 
Vol. 23, No. 3

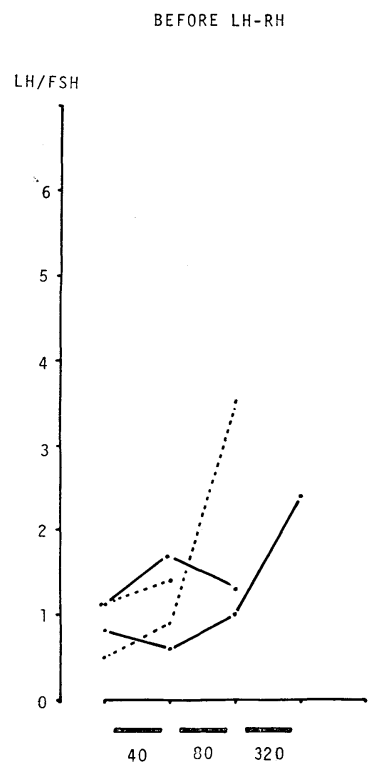

AFTER LH-RH
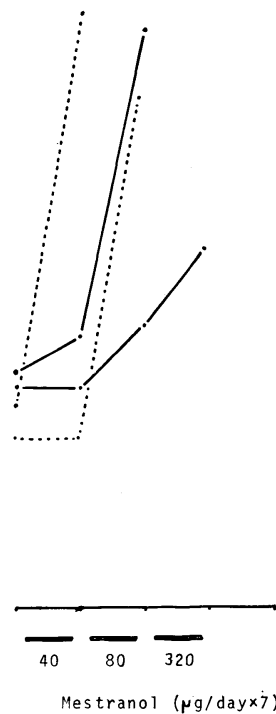

Fig. 5. LH/FSH after LH-RH administration to 4 patients with high gonadotropin levels who were primed with mestranol.

LH was increased again after a transient reduction of the release. So that, $\mathrm{LH} / \mathrm{FSH}$ after administration of LH-RH was increased and reached the same level as the normal ovulatory peak (Fig. 5).

\section{Discussion}

Daily variations of serum $\mathrm{LH}$ and FSH levels during normal menstrual cycles were well known. Snyder et al. (1973) reported that a constantly changing pattern of the relative concentration of $\mathrm{LH}$ and $\mathrm{FSH}$ was seen in the normal cycle, when the ratios of LH and FSH were calculated. There is a gradual increase in LH "dominance", reaching a maximum at the $\mathrm{LH}$ peak followed by a gradual decline and return toward the initial FSH predominance. The data in our study show the same changing pattern as that reported by Snyder et al. (1973) and Minagawa et al. (1972).
In anovulatory women, a mean LH/FSH in the low Ed group was lower than that during the follicular phase in ovulatory women and a mean LH/FSH in the moderate Ed and the high Ed group was higher than that during the follicular phase in ovulatory women. Rose et al. (1970) suggested that an adequate amount of FSH and LH, perhaps an appropriate ratio of the two, was essential for the proper maturation of a follicle. Therefore, the abnormal ratio of $\mathrm{LH}$ to $\mathrm{FSH}$ in anovulatory women might be unfavorable to the maturation of an ovarian follicle.

As an attempt to induce ovulation, synthetic LH-RH has been used recently. Only when the ovarian follicle is already mature, LH-RH is effective (Igarashi et al., 1974). This fact suggests that synthetic LH-RH releases enough gonadotropins to rupture a mature follicle, and the present study exhibited that a mean LH/FSH after administration of LH-RH during the follicular phase in ovulatory women was the same value as the mean ratio as the ovulatory peak in the normal menstrual cycle. But in anovulatory women, the mean LH/ FSH of the low Ed group was significantly lower than the mean ratio at the ovulatory peak and the mean LH/FSH of the moderate $\mathrm{Ed}$ and the high $\mathrm{Ed}$ group was significantly higher than that at the ovulatory peak. Hisaw (1926) found in a study of ovariectomized animals that a mature ovarian follicle was ruptured under the condition of a definite ratio of FSH to LH. In the light of Hisaw's paper, the LH/FSH after LH-RH injection in anovulatory women seemed to be an unfavorable condition of the ratio for the rupture of the follicle as compared with the LH/FSH after the treatment in ovulatory women.

Arimura and Schally (1974) reported that gonadal steroids effected the pituitary response to $\mathrm{LH}-\mathrm{RH}$, thereby modifying the magnitude of the secretion of gonadotropins as well as the relative ratio of released 
LH/FSH. Our preliminary report (Uemura et al., 1975) also suggests that the responses of pituitary gonadotropins to LH-RH are affected by serum Ed levels. So that, patients with primary ovarian failure and elevated gonadotropin levels in serum who belong to the low Ed group were treated with mestranol. The increased doses of mestranol treatment elevated the LH/FSH after administration of LH-RH to the same ratio as observed in the ovulatory peak.

These results in the present study demonstrated that responses of pituitary gonadotropins to LH-R.H in anovulatory women were different from those in ovulatory women. In anovulatory women, the responses of gonadotropins to LH-RH in some of low Ed patients are responsible for low levels of Ed, but the responses in the moderate and the high Ed group are not responsible for levels of Ed but for something else. And the abnormality of the responses in anovulatory women seems to be unfavorable to ovulation.

\section{Acknowledgements}

The authors would like to thank Dr. M. Kawakami, Professor of Physiology at Yokohama City University for helpful suggestions. They are also grateful to Dr. A. Kanbegawa, Teikoku Hormone Mfg., Co. Ltd. for generous gifts of anti-estradiol serum.

\section{References}

Arimura, A. and A. V. Schally Biological Rhythms in Neuroendocrine Activity (edited by M. Kawakami) Igaku Shoin, Tokyo, p. 72 (1974).

Hisaw, F. L. (1926). Proc. Soc. Exptl. Biol. Med. 23,661 .

Igarashi, M., K. Taya, J. Ishikawa and M. Yamasaki Biological Rhythms in Neuroendocrine Activity (edited by M. Kawakami) Igaku Shoin, Tokyo, p. 91 (1974).

Kooguchi, J., T. Uemura, N. Suzuki and Y. Shiojima (1976). Jap. J. Fert. \& Ster. 21, 40. (In Japanese)

Makino, T. (1973). Folia Endocrinol. Japon. 49, 576. (In Japanese)

Minagawa, J., T. Aono, K. Kawamura, O. Tanizawa and K. Kurachi (1972). Folia Endocrinol. Japon. 48, 387. (In Japanese)

Ross, G. T., C. M. Cargille, M. B. Lipsett, P. L. Rayford, J. R. Marshall, C. A. Strott and D. Rodbard (1970). Rec. Prog. Hormone Res. 26, 1. Snyder, D. L., R. B. Jaffe, A. R. Midgley, Jr. and E. Bolte (1973). Fertil. Steril. 24, 706.

Uemura, T., J. Kooguchi and Y. Shiojima (1974). Folia Endocrinol. Japon. 50, 1292. (In Japanese)

Uemura, T., J. Kooguchi, N. Suzuki and Y. Shiojima (1975). Folia Endocrinol. Japon. 51, 644. (In Japanese)

Yen, S. S. C., G. Vandenberg, R. Rebar and Y. Ehara (1972). J. Clin. Endocrinol. Metab. 35, 931. 